\title{
The alga Bryothamnion seaforthii contains carbohydrates with antinociceptive activity
}

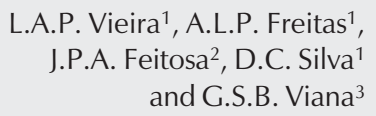

\author{
Departamentos de ${ }^{1}$ Bioquímica e Biologia Molecular, \\ ${ }^{2}$ Química Orgânica e Inorgânica, and ${ }^{3}$ Fisiologia e Farmacologia, \\ Universidade Federal do Ceará, Fortaleza, CE, Brasil
}

Correspondence
G.S.B. Viana
Departamento de Fisiologia e
Farmacologia, UFCe
Rua Cel. Nunes de Melo, 1127
Rodolfo Teófilo
60430-270 Fortaleza, CE
Brasil
Research supported by CNPq.
$\ldots \ldots \ldots . . . \ldots \ldots$
Received January 14,2003
Accepted April 13, 2004
$\ldots \ldots \ldots \ldots$

\section{Abstract}

Bryothamnion seaforthii, a red alga common to the Northeastern coast of Brazil, was used to prepare the protein fraction F0/60 by ammonium sulfate precipitation. The chromatography of F0/60 on DEAE-Sephadel column resulted in two lectin fractions, PI and PII, which have antinociceptive properties in rodents. We determined the antinociceptive activity of the PII fraction and of a carbohydratecontaining fraction (CF) in mice. The CF was prepared from the dried algae, after digestion with $100 \mathrm{mM}$ sodium acetate, $\mathrm{pH}$ 6.0, containing $5 \mathrm{mM}$ cysteine, EDTA and $0.4 \%$ papain, at $60^{\circ} \mathrm{C}$. A $10 \%$ cetylpyridinium chloride was added to the filtrate, and the precipitate was dissolved with $2 \mathrm{M} \mathrm{NaCl}$ :ethanol (100:15, v/v) followed by the carbohydrate precipitation with ethanol. The final precipitate, in acetone, was dried at $25^{\circ} \mathrm{C}$. The PII fraction markedly inhibited acetic acidinduced abdominal writhing after ip administration (control: $27.1 \pm$ 2.20; PII $0.1 \mathrm{mg} / \mathrm{kg}: 5.5 \pm 1.85 ; 1 \mathrm{mg} / \mathrm{kg}: 1.6 \pm 0.72$ writhes $/ 20 \mathrm{~min}$ ) and after oral administration (control: $32.0 \pm 3.32 ; \mathrm{PII} 0.1 \mathrm{mg} / \mathrm{kg}$ : $13.1 \pm 2.50$; $1 \mathrm{mg} / \mathrm{kg}: 9.4 \pm 3.96$ writhes $/ 20 \mathrm{~min}$ ). PII was also effective against both phases of pain induced by $1 \%$ formalin (control, ip: $48.2 \pm 2.40$ and $27.7 \pm 2.56 \mathrm{~s}$; PII $1 \mathrm{mg} / \mathrm{kg}, i p: 34.3 \pm 5.13$ and $5.6 \pm 2.14 \mathrm{~s}$; control, po: $44.5 \pm 3.52$ and $25.6 \pm 2.39 \mathrm{~s} ;$ PII $5 \mathrm{mg} / \mathrm{kg}, p o: 26.5 \pm 4.67$ and $15.3 \pm 3.54$ $\mathrm{s}$ for the 1st and 2nd phases, respectively) and in the hot-plate test. The CF (ip) also displayed significant antinociceptive properties in all tests but at higher doses ( 1 and $5 \mathrm{mg} / \mathrm{kg}$, ip and $p o$ ). Thus, CF at the dose of $5 \mathrm{mg} / \mathrm{kg}$ significantly inhibited writhes (ip: $7.1 \pm 2.47$ and po: $14.5 \pm 2.40$ writhes $/ 20 \mathrm{~min})$ as well as the $1 \mathrm{st}(p o: 19.6 \pm 1.74 \mathrm{~s})$ and 2 nd (po: $7.1 \pm 2.24 \mathrm{~s}$ ) phases of the formalin test compared to controls $i p$ and po. The antinociceptive effects of both the PII and CF in the formalin and hot-plate tests were prevented at least partially by pretreatment with the opioid receptor antagonist naloxone $(2 \mathrm{mg} / \mathrm{kg}$, $s c$ ). Moreover, both fractions retained antinociceptive activity in the acetic acid-induced writhing test following heating, a procedure which abolished the hemagglutinating activity of the fraction, presumably due to lectins also present. Finally, both fractions also prolonged the barbiturate-induced sleeping time. These results indicate that carbohydrate molecules present in the PII (26.8\% carbohydrate) and CF ( $21 \%$ of the alga dried weight) obtained from B. seaforthii display pronounced antinociceptive activity which is resistant to heat denaturation and is mediated by an opioid mechanism, as indicated by naloxone inhibition.
Key words

- Algae

- Antinociceptive activity

- Carbohydrate

- Bryothamnion seaforthii 


\section{Introduction}

Among the several algae species used in popular medicine are those belonging to the genera Codium, Sargassum, Gracilaria, and Hypnea $(1,2)$. Several alga species occurring along the northeastern Brazilian coast are known to present the same type of biological activity such as the hemagglutinating activity (3-5). It has been speculated that some of the chemical constituents of algae, such as sulfated polysaccharides, may be responsible for their fibrinolytic, antithrombotic, anticoagulant, and antiviral activities (6-14). Furthermore, polysaccharides from the red microalga Porphyridium sp have been shown to be potent hypocholesterolemic agents (15). Sulfated polysaccharides are part of a complex group of macromolecules with a wide range of important biological properties and some of these compounds extracted from red algae might be used as low-cost, broadspectrum antiviral agents (9). Recently (16), sulfated polysaccharides from red microalgae were shown to present potent anti-inflammatory properties.

In addition, several types of lectins isolated from marine algae and hemagglutinins from red algae have been extensively studied and lectins from the marine red alga species Bryothamnion seaforthii and B. triquetrum (5) occurring along the northeastern Brazilian coast have also been investigated. We have reported that a lectin, which we named fraction PI, isolated from these species presents antinociceptive activity in several experimental models in mice (17). Significant anti-inflammatory, analgesic and free radical scavenging activities have also been detected in other species such as Chlorella stigmatophora and Phaeodactylum tricornutum (18). Recently (19) we demonstrated that $B$. seaforthii and B. triquetrum present not only one but two different fractions containing lectins (PI and PII). The lectins of both species have a high carbohydrate content which could be responsible, at least in part, for the antinociceptive activity.

The objective of the present investigation was to determine the mechanism of the antinociception observed in the PII lectin fraction and the role of the sulfated polysaccharides in this pharmacological effect.

\section{Material and Methods}

\section{Drugs and reagents}

Bovine serum albumin, naloxone, sodium pentobarbital, and cetylpyridinium chloride were purchased from Sigma (St. Louis, MO, USA). Morphine sulfate was from Cristália do Brasil S/A (Itapira, SP, Brazil) and cysteine was from Riedel-de-Haen (Seelze, Germany). Formaldehyde was purchased from Reagen (São Paulo, SP, Brazil) and acetic acid from Vetec (São Paulo, SP, Brazil). All other drugs and reagents used were of analytical grade.

\section{Plant material}

Bryothamnion seaforthii was collected on the northeastern Brazilian coast (Fleixeiras Beach, Trairi, Ceará State, Brazil), brought to the laboratory in water-ice bags and kept at $-20^{\circ} \mathrm{C}$ until use. The alga was identified by Dr. D.I.A. Teixeira (Universidade Federal do Ceará, Fortaleza, CE, Brazil) and a sample was deposited in the Prisco Bezerra Herbarium of the Federal University of Ceará (voucher No. 30.850).

\section{Chemical fractionation}

The F0/60 fraction and the lectin were prepared as described in Ref. 5. Briefly, algae were thawed, rinsed with distilled water, ground to a fine powder under liquid nitrogen, stirred for $4 \mathrm{~h}$ with three volumes of 20 $\mathrm{mM}$ phosphate buffer, $\mathrm{pH}$ 7.0, containing $0.15 \mathrm{M} \mathrm{NaCl}$, filtered through a nylon mesh, and centrifuged at $7,000 \mathrm{~g}$ for $30 \mathrm{~min}$ at $4^{\circ} \mathrm{C}$. The supernatant was acidified to $\mathrm{pH} 1.0$ with 
$2 \mathrm{~N} \mathrm{HCl}$, kept for $16 \mathrm{~h}$ under refrigeration, centrifuged and adjusted to $\mathrm{pH} 7.0$ with $2 \mathrm{~N}$ $\mathrm{NaOH}$, followed by the addition of ammonium sulfate crystals to $60 \%$ saturation. After $16 \mathrm{~h}$, the precipitate was recovered by centrifugation (F0/60), resuspended in distilled water and dialyzed.

Fractions containing lectins (PI and PII) were obtained from lyophilized F0/60 by chromatography on DEAE-cellulose. The column was equilibrated and eluted with 20 $\mathrm{mM}$ sodium phosphate buffer, $\mathrm{pH}$ 7.6, followed by elution with $1 \mathrm{M} \mathrm{NaCl}$. Active fractions (PI and PII) were re-chromatographed on the same column, combined, dialyzed against water, and lyophilized. The procedure for isolation of the fraction containing lectins is a simple and reproducible one, and provides an average yield of 10-15 $\mathrm{mg}$ protein $/ \mathrm{kg}$ fresh algae. In the present study, only the PII fraction was used, and this fraction containing lectins, identified by hemagglutinating reaction, was dissolved in distilled water before use.

For the preparation of the fraction containing carbohydrate $(\mathrm{CF})$, freshly collected algae were washed with distilled water and dried at $35^{\circ} \mathrm{C}$. Twenty grams of dried algae was wet in $1 \%(\mathrm{w} / \mathrm{v})$ sodium hypochlorite and washed with distilled water. The dried tissue was suspended in $500 \mathrm{ml}$ of $100 \mathrm{mM}$ sodium acetate buffer, $\mathrm{pH}$ 6.0, containing 5 mM cysteine, 5 mMEDTA and $0.4 \%$ papain, and incubated at $60^{\circ} \mathrm{C}$ for $24 \mathrm{~h}$. The mixture was filtered and the supernatant solution saved. The residue was washed with distilled water and filtered and the two supernatants combined.

Sulfated polysaccharides were precipitated with $17 \mathrm{ml}$ of $10 \%(\mathrm{w} / \mathrm{v})$ cetylpyridinium chloride. After standing at room temperature for $48 \mathrm{~h}$, the mixture was centrifuged at 2,500 $\mathrm{g}$ for $20 \mathrm{~min}$ at $4^{\circ} \mathrm{C}$ and pellets were washed with $600 \mathrm{ml}$ of a $0.05 \%(\mathrm{w} / \mathrm{v})$ cetylpyridinium chloride solution and centrifuged at 2,500 $\mathrm{g}$ for $20 \mathrm{~min}$. The remaining pellet was then dissolved with $150 \mathrm{ml}$ of
$2 \mathrm{M} \mathrm{NaCl}$ :ethanol (100:15, v/v) and precipitated with $300 \mathrm{ml}$ absolute ethanol. After 24 h at $4^{\circ} \mathrm{C}$, the precipitate was collected by centrifugation at 2,500 $\mathrm{g}$ for $20 \mathrm{~min}$ at $4^{\circ} \mathrm{C}$, washed with $300 \mathrm{ml}$ of $80 \%$ ethanol, followed by the same volume of absolute ethanol, and finally by the same volume of acetone. The final precipitate was dried at room temperature. The yield was about $21 \%$ by weight. The carbohydrate-containing fraction was dissolved in distilled water before use. For the determination of the degree of sulfation, the carbohydrate fraction was submitted to infrared spectrophotometry in $\mathrm{KBr}$ from 4000 to $400 \mathrm{~cm}^{-1}$ using a model 100 Perkin Elmer spectrophotometer (Perkin Elmer, San Francisco, CA, USA). Both the PII and carbohydrate fractions were dissolved in distilled water before use and their $\mathrm{pH}$ was 7.0. This vehicle was used in all control groups.

\section{Animals}

Swiss mice of both sexes weighing 20 to $25 \mathrm{~g}$, from the Animal House of the Federal University of Ceará, maintained on a 12-h light/dark cycle with free access to water and food were used. Since both the PII and carbohydrate fractions were dissolved in distilled water, this vehicle was used for all control groups. Experiments were carried out according to the Guide for the Care and Use of Laboratory Animals of the US Department of Health and Human Services.

\section{Evaluation of antinociceptive activity}

Writhing test. Male and female mice were used in each of the two experiments performed. Animals were treated with the PII or carbohydrate fractions from $B$. seaforthii for $30 \mathrm{~min}$ (intraperitoneal, ip, administration) or $60 \mathrm{~min}$ (oral, po, administration) before receiving a $0.6 \%$ acetic acid injection $(10 \mathrm{ml} / \mathrm{kg}, i p)$, and the number of contractions was recorded for 20 min after a 10-min 
interval (20). Naloxone ( $2 \mathrm{mg} / \mathrm{kg}$, ip) was injected 15 min before the fractions or morphine (used as standard).

Formalin test. Twenty microliters of a $1 \%$ formalin solution was injected into the right hind paw of male Swiss mice (25 g), and the licking time was recorded after the first $5 \mathrm{~min}$ (1st phase) and after $20 \mathrm{~min}$ (2nd phase), for 5 min each time. Animals were pretreated with lectin or carbohydrate fractions, 30 or $60 \mathrm{~min}$ before for ip or po administration, respectively. Naloxone, an opioid antagonist, was injected $15 \mathrm{~min}$ before the fractions, and morphine was used as standard $(21,22)$.

Hot-plate test. Male Swiss mice (25 g) were pre-selected according to their reactions to a thermal stimulus (jumping or licking of hind limbs when placed on a hot plate at $55^{\circ} \mathrm{C}$ ). Latency times were recorded immediately before and 30, 60, 90, and $120 \mathrm{~min}$ after drug administration up to a maximum time of $40 \mathrm{~s}$ in order to avoid paw lesions (23). In order to detect a possible involvement of the opioid system, animals were pretreated with naloxone $15 \mathrm{~min}$ before treatment with the fractions or morphine.

\section{Barbiturate-induced sleeping time}

Sleep was induced in female mice by ip administration of $40 \mathrm{mg} / \mathrm{kg}$ sodium pentobarbital by the method of Ferrini et al. (24). Sodium pentobarbital was injected $30 \mathrm{~min}$ (ip) or $60 \mathrm{~min}$ ( $p o$ ) after the administration of PII or carbohydrate fractions and latency time to sleep (time to lose the righting reflex) and sleeping time (duration of time to recover the righting reflex) were determined.

\section{Hemagglutination assay}

Hemagglutination assays were conducted on rabbit erythrocytes according to the procedure described by Chiles and Bird (25). Approximately $4 \mathrm{ml}$ of the erythrocyte suspension was washed four times with three volumes of cold PBS and the final pellet was used to prepare a $2 \%(\mathrm{v} / \mathrm{v})$ suspension. Serial two-fold dilutions of the algal fractions were then prepared with PBS and added to 96-well round bottom microtiter plates. An equal volume of the erythrocyte suspension was added to each well and the plates were shaken and allowed to stand at room temperature for $24 \mathrm{~h}$. The activity of the fractions was reported as the minimum amount of protein causing agglutination.

\section{Statistical analysis}

Data were analyzed statistically by ANOVA and by the Bonferroni $t$-test as the post hoc test, with the level of significance set at $\mathrm{P}<0.05$. This test is based on the Student $t$ statistic and adjusts the level of significance observed to the fact that multiple comparisons are made. We also used the Student-Newman-Keuls test to detect homogeneity of the subset means.

\section{Results}

Table 1 shows that acetic acid-induced abdominal contractions were reduced by 80 and $94 \%$ in mice after ip administration of 0.1 and $1 \mathrm{mg} / \mathrm{kg}$ PII, respectively. Somewhat lower inhibitions (59 and 71\%) were observed after oral administration of the same doses. Similarly, the carbohydrate fraction significantly decreased the acetic acidinduced abdominal contractions by 49 and $74 \%$ at ip doses of 1 and $5 \mathrm{mg} / \mathrm{kg}$.

In the formalin test (Table 2), PII also produced dose-dependent inhibitions (50 and $80 \%$ ) predominantly of the 2 nd phase of the response after administration of 0.1 and 1 $\mathrm{mg} / \mathrm{kg}$, ip, respectively. At the higher dose (1 $\mathrm{mg} / \mathrm{kg}$, ip $)$, a significant inhibition was observed during the first phase as well (29\% inhibition). Similar to morphine, naloxone reversed the effect of PII, indicating the involvement of the opioid system. When the carbohydrate fraction was administered $i p$ at 
the dose of $5 \mathrm{mg} / \mathrm{kg}$ no significant effect was detected, whereas 23 and 56\% inhibitions of the 1st and 2nd phases, respectively, were observed after ip administration of $10 \mathrm{mg} /$ $\mathrm{kg}$. These effects were also totally blocked by pretreatment with naloxone. Percent inhibitions were 40 and $56 \%$ (1st phase) and 40 and $72 \%$ (2nd phase) after the oral administration of $5 \mathrm{mg} / \mathrm{kg}$ PII and of the carbohydrate fraction, respectively (Table 2 ).

In the hot-plate test (Figure 1), increases in the reaction time to thermal stimuli of 31 , 58 and $37 \%$, and 47,45 and $48 \%$ were detected 30 and $60 \mathrm{~s}$ after PII administration at doses of 1,5 and $10 \mathrm{mg} / \mathrm{kg}$, ip, respectively. In this case, the effect was also totally reversed by naloxone pretreatment. Morphine, used as a positive standard, increased the reaction time to thermal stimuli by 75 and $71 \%$ after 30 and $60 \mathrm{~min}$, respectively. As expected, in this case, the effect was totally blocked in the presence of naloxone. The carbohydrate fraction $(5 \mathrm{mg} / \mathrm{kg}$, ip $)$ increased the reaction time to thermal stimuli by 25,38 and 38\% 30, 60 and 90 min after its administration, respectively. Similarly, the administration of $10 \mathrm{mg} / \mathrm{kg}$, po, also increased the reaction time by 37 and $28 \%$ after 60 and 90 min, respectively. The effect of the carbohydrate fraction was reversed by pretreatment with naloxone (Figure 1).

Administration of the PII fraction (1 and $2 \mathrm{mg} / \mathrm{kg}$ ) significantly increased the barbiturate-induced sleeping time by 52 and $55 \%$ and by 47 and 55\% after ip and oral administration, respectively. Similarly, the carbohydrate fraction ( 1 and $5 \mathrm{mg} / \mathrm{kg}$ ) increased sleeping time by 60 and $58 \%$ and by 40 and $73 \%$ after $i p$ and oral administration, respectively (Table 3).

Although no hemagglutinating activity was demonstrated for the PII fraction after heating at $120^{\circ} \mathrm{C}$ for $15 \mathrm{~min}$, its antinociceptive effect was well maintained (Table 4) and the inhibition of abdominal contractions was similar before and after heating (about 94\%). On the other hand, while the inhibition of
Table 1. Antinociceptive effect of PII and carbohydrate fractions from Bryothamnion seaforthii on acetic acid-induced abdominal contractions in female Swiss mice.

\begin{tabular}{|c|c|c|}
\hline Group & No. of abdominal contractions/20 min & $\%$ Inhibition \\
\hline Control (ip) & $27.1 \pm 2.20(19)$ & - \\
\hline \multicolumn{3}{|l|}{ PII fraction (ip) } \\
\hline $0.1 \mathrm{mg} / \mathrm{kg}$ & $5.5 \pm 1.85(8)^{*}$ & 80 \\
\hline $1.0 \mathrm{mg} / \mathrm{kg}$ & $1.6 \pm 0.72(7)^{*}$ & 94 \\
\hline \multicolumn{3}{|c|}{ Carbohydrate fraction (ip) } \\
\hline $0.1 \mathrm{mg} / \mathrm{kg}$ & $25.4 \pm 5.67(7)$ & - \\
\hline $1.0 \mathrm{mg} / \mathrm{kg}$ & $13.9 \pm 1.53(12)^{*}$ & 49 \\
\hline $5.0 \mathrm{mg} / \mathrm{kg}$ & $7.1 \pm 2.47(7)^{*}$ & 74 \\
\hline Control (po) & $32.0 \pm 3.32(11)$ & - \\
\hline \multicolumn{3}{|c|}{ PII fraction (po) } \\
\hline $0.1 \mathrm{mg} / \mathrm{kg}$ & $13.1 \pm 2.50(7)^{*}$ & 59 \\
\hline $1.0 \mathrm{mg} / \mathrm{kg}$ & $9.4 \pm 3.96(7)^{*}$ & 71 \\
\hline \multicolumn{3}{|c|}{ Carbohydrate fraction (po) } \\
\hline $1.0 \mathrm{mg} / \mathrm{kg}$ & $16.6 \pm 2.93(16)^{*}$ & 48 \\
\hline $5.0 \mathrm{mg} / \mathrm{kg}$ & $14.5 \pm 2.40(16)^{*}$ & 55 \\
\hline
\end{tabular}

Table 2. Antinociceptive effect of the PII and carbohydrate fractions from Bryothamnion seaforthii on the formalin test in male Swiss mice.

\begin{tabular}{|c|c|c|c|c|}
\hline \multirow[t]{2}{*}{ Group } & \multirow[t]{2}{*}{ 1st phase } & \multirow[t]{2}{*}{ 2nd phase } & \multicolumn{2}{|c|}{ \% Inhibition } \\
\hline & & & 1st phase & 2nd phase \\
\hline Control, ip (25) & $48.2 \pm 2.40$ & $27.7 \pm 2.56$ & - & - \\
\hline $0.1 \mathrm{mg} / \mathrm{kg}$ PII, ip (8) & $46.9 \pm 5.63$ & $13.9 \pm 3.08^{a}$ & - & 50 \\
\hline 1.0 mg/kg PII, ip (8) & $34.3 \pm 5.13^{*}$ & $5.6 \pm 2.14^{a}$ & 29 & 80 \\
\hline Mor, ip (11) & $11.4 \pm 3.07^{*}$ & $5.4 \pm 1.93^{a}$ & 76 & 81 \\
\hline Nal, sc (11) & $49.2 \pm 3.25$ & $23.2 \pm 2.82$ & - & - \\
\hline $\mathrm{Nal}+\mathrm{Mor}(5)$ & $40.8 \pm 6.04$ & $29.6 \pm 3.36^{b}$ & - & - \\
\hline $\mathrm{Nal}+1$ mg/kg PII (8) & $44.5 \pm 8.41$ & $12.0 \pm 2.26^{a, c}$ & - & 57 \\
\hline 5 mg/kg CF, ip (8) & $41.6 \pm 4.16$ & $23.3 \pm 2.72$ & - & - \\
\hline 10 mg/kg CF, ip (21) & $37.1 \pm 2.81$ & $12.2 \pm 1.74^{a}$ & 23 & 56 \\
\hline $\mathrm{Nal}+10 \mathrm{mg} / \mathrm{kg} \mathrm{CF}$ (14) & $45.9 \pm 1.78$ & $21.6 \pm 3.24^{d}$ & - & - \\
\hline Control, po (12) & $44.5 \pm 3.52$ & $25.6 \pm 2.39$ & - & - \\
\hline $1 \mathrm{mg} / \mathrm{kg}$ PII, po (6) & $44.7 \pm 3.11$ & $31.8 \pm 5.48$ & - & - \\
\hline 5 mg/kg PII, po (6) & $26.5 \pm 4.67^{*}$ & $15.3 \pm 3.54^{a}$ & 40 & 40 \\
\hline 5 mg/kg CF, po (7) & $19.6 \pm 1.74^{*}$ & $7.1 \pm 2.24^{a}$ & 56 & 72 \\
\hline
\end{tabular}

Distilled water $(10 \mathrm{ml} / \mathrm{kg})$ was used as control. Data are reported as mean $\pm \mathrm{SEM}$ for the number of animals indicated in parentheses. $\mathrm{Nal}=$ naloxone, $2 \mathrm{mg} / \mathrm{kg}, s c$; Mor = morphine, $5 \mathrm{mg} / \mathrm{kg}$, ip. aP $<0.05$ vs control, ${ }^{\mathrm{b} P}<0.05$ vs morphine, ${ }^{\mathrm{CP}}<0.05$ vs $1 \mathrm{mg} / \mathrm{kg}$ PII and $\mathrm{dP}<0.05 \mathrm{vs} 10 \mathrm{mg} / \mathrm{kg}$ carbohydrate fraction (CF) (ANOVA and Student-Newman-Keuls post hoc test). 
hemagglutinating activity was zero before heating it was $100 \%$ after heating.

Table 4 shows the treatment of the carbohydrate fraction with $1 \mathrm{M} \mathrm{NaOH}$ followed by heating at $80^{\circ} \mathrm{C}$ for $1 \mathrm{~h}$ to destroy carbohydrate sulfate groups. This treatment (after $\mathrm{pH}$ adjustment to 7.0 with $1 \mathrm{~N} \mathrm{HCl}$ ) did not change significantly the antinociceptive effect of the fraction, as demonstrated in the writhing test with mice. Inhibition of about $90 \%$ was observed with PII at the dose of 2 $\mathrm{mg} / \mathrm{kg}$, ip, before and after heating. Simi-
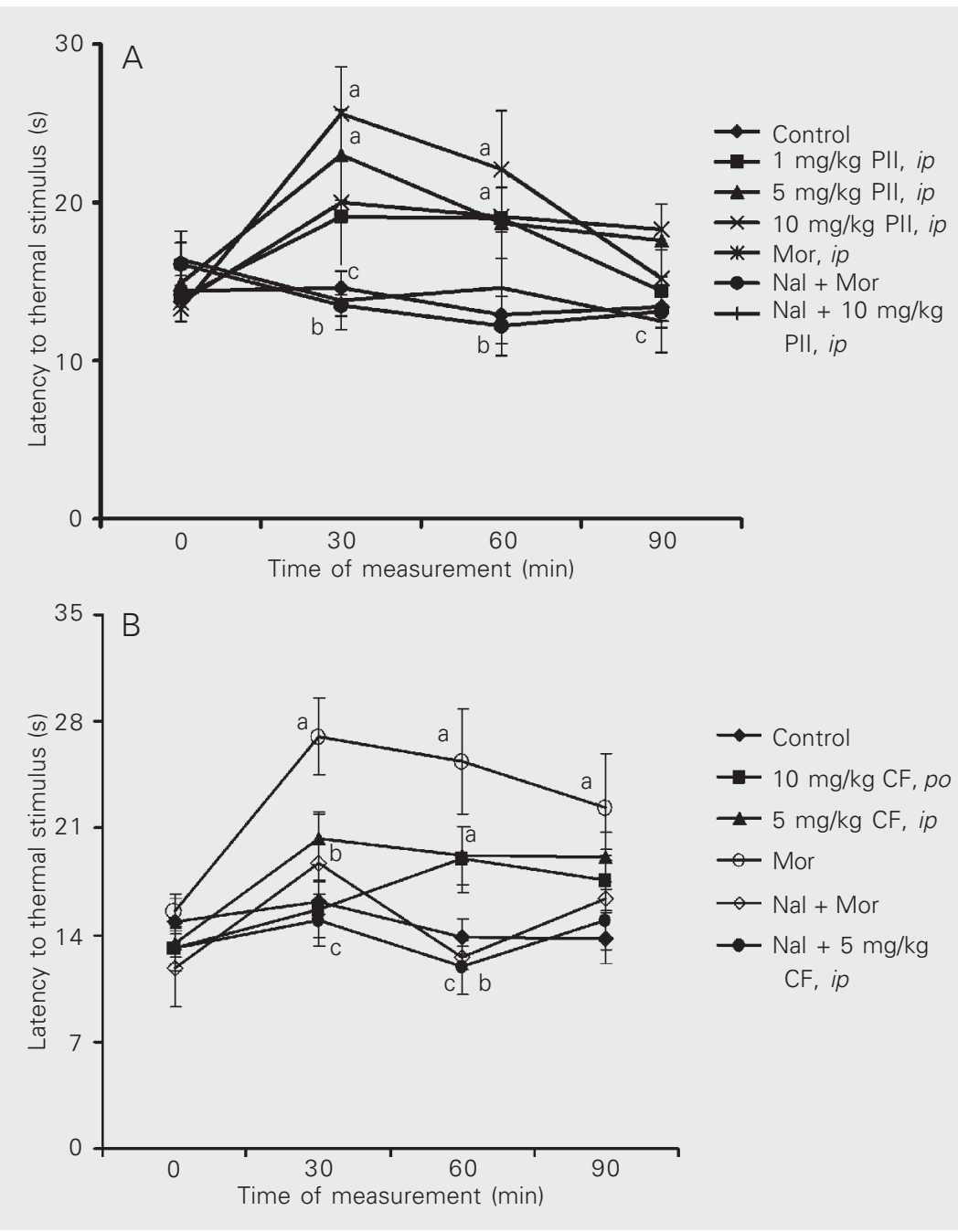

Figure 1. Effect of PII (A) and carbohydrate (B) fractions from Bryothamnion seaforthii on the hot-plate test in male mice. Data are reported as means \pm SEM. $P<0.05{ }^{a} v s$ controls, ${ }^{b}$ vs morphine, ${ }^{c}$ Vs $10 \mathrm{mg} / \mathrm{kg}$ Pll or $5 \mathrm{mg} / \mathrm{kg}$ CF at the same period of time (ANOVA and Bonferroni as a post hoc test). CF $=$ carbohydrate fraction; Mor $=$ morphine, $4 \mathrm{mg} / \mathrm{kg}, i p$; $\mathrm{Nal}=$ naloxone, $2 \mathrm{mg} / \mathrm{kg}, \mathrm{sc}$. larly, percent inhibition ranged from 70 to $84 \%$ (before heating) and from 86 to $97 \%$ (after heating), with the administration of the carbohydrate fraction $(1,5$ and $20 \mathrm{mg} / \mathrm{kg}$, ip). This treatment decreased by $75 \%$ the degree of sulfation of the carbohydrate fraction, indicating that sulfate groups are not important for antinociception.

\section{Discussion}

Sulfated polysaccharides are present in several marine organisms, including sponges (26), marine invertebrates (10), and red algae $(15,27)$. Sulfated polysaccharides have many biological functions which depend on the binding of specific carbohydrate structures to several types of protein molecules, including lectins (11,28-31). Recently reported data (14) have shown that polysaccharides isolated from brown algae possess significant anti-inflammatory and antithrombotic activities. In addition, polysaccharides with a fucosylated chondroitin sulfate structure were shown to present anticoagulant and antithrombotic activities (10).

The anticoagulant and antiproliferative effects of low molecular weight fucans with different sulfate content depend on their degree of sulfation (11). Polysaccharides, identified as sulfated D-galactans isolated from marine red algae, present anticoagulant activity whose potency is a function of the chemical structure of the molecule, and some investigators have suggested that conformational analysis may explain the differences in biological activity among sulfated polysaccharide molecules. In addition, a pharmacological study (18) of hydrosoluble and liposoluble extracts of the marine microalgae Chlorella stigmatophora and Phaeodactylum tricornutum showed significant anti-inflammatory, analgesic, and free scavenging activities in the hydrosoluble components from both species. No activity was detected in the liposoluble fractions and the activated constituents present in the hydrosoluble fractions 
probably are of a polysaccharide nature.

A recent study (32) demonstrated antiulcer activity of polysaccharides from marine algae and antipeptic activity has been observed in several types of sulfated polysaccharides such as dextran sulfate, carrageenan and fucoidan $(29,33)$. The cited investigators showed that non-sulfated polysaccharides such as mannan and dextran had no antipeptic activity.

In the present study, we showed that the lectin fraction (PII) isolated from the $B$. seaforthii $\mathrm{F} 0 / 60$ fraction as well as the carbohydrate fraction isolated from the fresh alga possess a potent and dose-related antinociceptive activity against acetic acid-induced abdominal contractions and in the formalin and hot-plate tests in mice. The effects were manifested after both ip and oral administration, indicating that active compounds are well absorbed by the gastrointestinal tract. It seems that sulfate moieties in the polysaccharide molecules are not involved in antinociception, since treatment of the carbohydrate fraction with $1 \mathrm{M} \mathrm{NaOH}$ followed by heating at $80^{\circ} \mathrm{C}$ for $1 \mathrm{~h}$ did not modify the effect. This treatment not only destroys the sulfate moieties but also denatures any protein/lectin present as a contaminant in the carbohydrate fraction.

In addition, in the formalin test, PII and the carbohydrate fraction seemed to act predominantly on the 2 nd phase of the response, suggesting that their antinociceptive effect is mainly against pain of an inflammatory nature. Both fractions were also active in the hot-plate test, significantly increasing the animal's reaction time to the thermal stimulus. The presence of the opioid antagonist naloxone reversed at least in part the antinociceptive effect, indicating the involvement of the opioid system in the effects of both PII and the carbohydrate fraction. The antinociceptive effect was also manifested at a central level since both fractions significantly increased the barbiturate-induced sleeping time in mice in a dose-dependent manner after both ip and oral administration. A maximum effect was already observed at the dose of $1 \mathrm{mg} / \mathrm{kg}$, ip. These data are

Table 3. Potentiation of the barbiturate-induced sleeping time in mice by the PII and carbohydrate fractions from Bryothamnion seaforthii.

\begin{tabular}{|c|c|c|}
\hline Group & Sleeping time (min) & $\%$ Potentiation \\
\hline Control (52) & $32.5 \pm 1.94$ & - \\
\hline \multicolumn{3}{|l|}{ Pll fraction } \\
\hline $0.5 \mathrm{mg} / \mathrm{kg}$, ip (10) & $30.4 \pm 3.80$ & - \\
\hline $1.0 \mathrm{mg} / \mathrm{kg}$, ip (20) & $49.5 \pm 3.65^{*}$ & 52 \\
\hline $2.0 \mathrm{mg} / \mathrm{kg}$, ip (20) & $50.5 \pm 3.60^{*}$ & 55 \\
\hline $0.5 \mathrm{mg} / \mathrm{kg}$, po (17) & $33.9 \pm 3.95$ & - \\
\hline $1.0 \mathrm{mg} / \mathrm{kg}$, po (21) & $47.7 \pm 3.44^{*}$ & 47 \\
\hline $2.0 \mathrm{mg} / \mathrm{kg}$, po (13) & $50.2 \pm 5.24^{*}$ & 55 \\
\hline Control (28) & $24.8 \pm 1.93$ & - \\
\hline \multicolumn{3}{|l|}{ Carbohydrate fraction } \\
\hline 1.0 mg/kg, ip (10) & $39.7 \pm 4.78^{*}$ & 60 \\
\hline $5.0 \mathrm{mg} / \mathrm{kg}$, ip (10) & $39.2 \pm 3.62^{*}$ & 58 \\
\hline $1.0 \mathrm{mg} / \mathrm{kg}$, po (10) & $34.8 \pm 2.32 *$ & 40 \\
\hline $2.0 \mathrm{mg} / \mathrm{kg}$, po (8) & $42.8 \pm 4.44^{*}$ & 73 \\
\hline
\end{tabular}

Table 4. Heating has no effect on the antinociceptive activities of the PII and carbohydrate fractions from Bryothamnion seaforthii on the acetic acid-induced abdominal contractions in mice.

\begin{tabular}{lccc}
\hline Group & $\begin{array}{c}\text { Dose/route of } \\
\text { administration }\end{array}$ & $\begin{array}{c}\text { No. of abdominal } \\
\text { contractions/20 min }\end{array}$ & $\%$ Inhibition \\
\hline Control & $10 \mathrm{ml} / \mathrm{kg}$, ip (6) & $28.7 \pm 3.50$ & - \\
PII fraction & & & \\
$\quad$ Before heating & $1.0 \mathrm{mg} / \mathrm{kg}$, ip (7) & $1.6 \pm 0.72$ & $94^{*}$ \\
& $2.0 \mathrm{mg} / \mathrm{kg}$, ip (8) & $3.0 \pm 1.56$ & $90^{*}$ \\
After heating & $2.0 \mathrm{mg} / \mathrm{kg}$, ip (6) & $1.8 \pm 1.34$ & $94^{*}$ \\
Control & $1.0 \mathrm{ml} / \mathrm{kg}$, ip (11) & $25.6 \pm 3.04$ & - \\
Carbohydrate fraction & & & \\
$\quad$ Before heating & $1.0 \mathrm{mg} / \mathrm{kg}$, ip (8) & $7.6 \pm 1.25$ & $70^{*}$ \\
& $5 \mathrm{mg} / \mathrm{kg}$, ip (7) & $4.1 \pm 1.36$ & $84^{*}$ \\
After heating & $20 \mathrm{mg} / \mathrm{kg}$, ip (24) & $4.5 \pm 1.19$ & $82^{*}$ \\
& $1 \mathrm{mg} / \mathrm{kg}$, ip (8) & $3.7 \pm 1.6$ & $86^{*}$ \\
& $5 \mathrm{mg} / \mathrm{kg}$, ip (8) & $1.4 \pm 0.37$ & $95^{*}$ \\
& $20 \mathrm{mg} / \mathrm{kg}$, ip (9) & $0.9 \pm 0.31$ & $97^{*}$ \\
\hline
\end{tabular}

The PII fraction was heated at $120^{\circ} \mathrm{C}$ in autoclave for $15 \mathrm{~min}$ and the carbohydrate fraction was treated with $1 \mathrm{~N} \mathrm{NaOH}$, adjusting final $\mathrm{pH}$ to 7.0 , followed by heating at $80^{\circ} \mathrm{C}$ for $1 \mathrm{~h}$. Male Swiss mice were used. Data are reported as mean \pm SEM for the number of animals indicated in parentheses.

${ }^{*} P<0.05$ vs control (ANOVA and Student Newman-Keuls as the post hoc test). 
consistent with the observation that both the PII and carbohydrate fractions decrease spontaneous locomotor activity in the open-field test, with no alteration in motor coordination as measured by the rota rod test (34).

The carbohydrate fraction was isolated from fresh algae and the yield was about $21 \%$. On the other hand, the carbohydrate content present in the lectin fraction (PII from the DEAE cellulose column) was reasonably high (close to $40 \%$ of the alga dried weight) and thus carbohydrate type compounds are probably responsible for the biological activity of the lectin. Also, the antinociceptive effect of the lectin fraction was well maintained after heating at $120^{\circ} \mathrm{C}$ for 15 min. Under these conditions, its hemagglutinating activity, used as an index of lectin activity, almost completely disappeared. In addition, we recently showed that the treatment of the F0/60 fraction with $0.1 \%$ sodium-dodecyl sulfate plus $0.1 \%$ mercaptoethanol, heating at $100^{\circ} \mathrm{C}$ for $1 \mathrm{~min}$, or the enzymatic treatment with a mixture of trypsin and papain, all of which cause protein denaturation, did not interfere with the observed antinociceptive effect (34). Besides, the removal of the sulfate groups from the carbohydrate molecules by treatment with
$1 \mathrm{~N} \mathrm{NaOH}$, followed by heating at $80^{\circ} \mathrm{C}$ for $1 \mathrm{~h}$, actually increased the antinociception observed with the carbohydrate fraction.

In conclusion, our results indicate that carbohydrate molecules present in the PII and carbohydrate fractions of the lectin from B. seaforthii display pronounced antinociceptive activity which is resistant to heat denaturation and is mediated to a significant extent via opioid mechanisms. Furthermore, the fact that heating did not change the action of PII, but both heating and $\mathrm{NaOH}$ treatment enhanced the action of the carbohydrate fraction, may suggest that the antinociceptive actions of both fractions are mediated by multiple carbohydrate compounds. The present findings, taken together with some of our previous data (18), show that lectins and carbohydrates from some species of red algae of the Northeastern Brazilian coast present significant analgesic and anti-inflammatory properties and could therefore be of potential therapeutical use.

\section{Acknowledgments}

The authors are grateful to Ms. Vilani Rodrigues Bastos for technical assistance.

\section{References}

1. Sampaio AH, Ainouz IL, Freitas ALP \& Benevides NMB (1993). Hemaglutininas de algas marinhas. Revista Brasileira de Fisiologia Vegetal, 5: 171-177.

2. Lim SN, Cheung PC, Ooi VE \& Ang PO (2002). Evaluation of antioxidative activity of extracts from a brown seaweed, Sargassum siliquastrum. Journal of Agriculture and Food Chemistry, 50: 38623866.

3. Ainouz IL \& Sampaio AH (1991). Screening of Brazilian marine algae for hemagglutinins. Botanica Marina, 34: 211-214.

4. Ainouz IL, Sampaio AH, Benevides NMB, Freitas ALP, Costa FHF, Carvalho MR \& Pinheiro-Joventino F (1992). Agglutination of enzyme treated erythrocytes by Brazilian marine algae. Botanica Marina, 35: 475-479.

5. Ainouz IL, Sampaio AH, Freitas ALP, Benevides NMB \& Mapurunga $S$ (1995). Comparative study on hemagglutinins from the red algae Bryothamnion seaforthii and B. triquetrum. Revista Brasileira de Fisiologia Vegetal, 7: 15-19.

6. Colliec S, Fisher AM, Tapon-Bretaudiere J, Boisson C, Durant P \& Josefonvicz J (1991). Anticoagulant properties of a fucoidan frac- tion. Thrombosis Research, 64: 143-154.

7. Nishino T, Aizu Y \& Nagumo T (1991). The influence of sulfate content and molecular weight of a fucan sulfate from the brown seaweed Ecklonia kurome on its antithrombin activity. Thrombosis Research, 64: 723-731.

8. Mauray S, Sternberg C, Theveniaux J, Millet J, Sinquin C, TaponBretaudiere J \& Fischer AM (1995). Venous antithrombotic and anticoagulant activities of a fucoidan fraction. Thrombosis and Haemostasis, 74: 1280-1285.

9. Carlucci MJ, Pujol CA, Ciancia M, Noseda MD, Matulewicz MC, Damonte EB \& Cerezo AS (1997). Antiherpetic and anticoagulant properties of carrageenans from the red seaweed Gigartina skottsbergii and their cyclized derivatives: correlation between structure and biological activity. International Journal of Biological Macromolecules, 20: 97-105.

10. Mourão PA \& Pereira MS (1999). Searching for alternatives to heparin: sulfated fucans from marine invertebrates. Trends in Cardiovascular Medicine, 9: 225-232.

11. Haroun-Bouhedja F, Ellouali M, Sinquin C \& Boisson-Vidal C (2000) 
Relationship between sulfate groups and biological activities of fucans. Thrombosis Research, 100: 453-459.

12. Duarte ME, Noseda DG, Noseda MD, Tulio S, Pujol CA \& Damonte EB (2001). Inhibitory effect of sulfated galactans from the marine alga Bostrychia montagnei on herpes simplex virus replication in vitro. Phytomedicine, 8: 53-58.

13. Choi HS \& Sa YS (2001). Fibrinolytic and antithrombotic protease from Spirodela polyrhiza. Bioscience, Biotechnology, and Biochemistry, 65: 781-786.

14. Trento F, Cattaneo F, Pescador R, Porta R \& Ferro L (2001). Antithrombin activity of an algal polysaccharide. Thrombosis Research, 102: 457-465.

15. Dvir I, Chayoth R, Sod-Moriah U, Shany S, Nyska A, Stark AH, Madar Z \& Arad SM (2000). Soluble polysaccharides and biomass of red microalga Porphyridium sp. alter intestinal morphology and reduce serum cholesterol in rats. British Journal of Nutrition, 84: 469-476.

16. Matsui MS, Muizzuddin N, Arad S \& Marenus K (2003). Sulfated polysaccharides from red microalgae have antiinflammatory properties in vitro and in vivo. Applied Biochemistry and Biotechnology, 104: 13-22.

17. Vieira LAP, Andrade MCH, Bastos MVR, Freitas ALP \& Viana GSB (1999). Efeito analgésico periférico e central da lectina de Bryothamnion seaforthii Kutzing. XIV Annual Meeting of the Federação de Sociedades de Biologia Experimental, Caxambu, MG, Brazil (Abstract 12.187, 392).

18. Guzman S, Gato A \& Calleja JM (2001). Antiinflammatory, analgesic and free radical scavenging activities of the marine microalgae Chlorella stigmatophora and Phaeodactylum tricornutum. Phytotherapy Research, 15: 224-230.

19. Viana GSB, Freitas ALP, Lima MML, Vieira LAP, Andrade MCH \& Benevides NMB (2002). Antinociceptive activity of sulfated carbohydrates from the red algae Bryothamnion seaforthii (Turner) Kütz. and B. triquetrum (S.G. Gmel.) M. Howe. Brazilian Journal of Medical and Biological Research, 35: 713-722.

20. Koster R, Anderson M \& De Beer EJ (1959). Acetic acid for analgesic screening. Federation Proceedings, 18: 412-417.

21. Fasmer OB, Berge OG \& Hole K (1985). Changes in nociception after lesions of descending serotoninergic pathways induced with 5,6-dihydroxytryptamine: different effects in the formalin and tail flick test. Neuropharmacology, 24: 729-734.

22. Hunskaar S \& Hole K (1987). The formalin test in mice: dissociation between inflammatory and non-inflammatory pain. Pain, 30: 103114.
23. Woolfe G \& MacDonald AD (1944). The evaluation of the analgesic action of pethidine hydrochloride (demerol). Journal of Pharmacology and Experimental Therapeutics, 80: 300-307.

24. Ferrini R, Miragoli G \& Taccardi B (1974). Neuropharmacological studies on SB 5833, a new psychotherapeutic agent of the benzodiazepine class. Arzneimittel-Forschung, 24: 2029-2032.

25. Chiles TC \& Bird KT (1989). A comparative study of animal erythrocyte agglutinins from marine algae. Comparative Biochemistry and Physiology, 94B: 107-111.

26. Zierer MS \& Mourão PA (2000). A wide diversity of sulfated polysaccharides are synthesized by different species of marine sponges. Carbohydrate Research, 328: 209-216.

27. Farias WRL, Valente AP, Pereira MS \& Mourão PAS (2000). Structure and anticoagulant activity of sulfated galactans. Journal of Biological Chemistry, 275: 29299-29307.

28. Mulloy B, Mourão PA \& Gray E (2000). Structure/function studies of anticoagulant sulphated polysaccharides using NMR. Journal of Biotechnology, 77: 123-135.

29. Shibata H, Kimura-Takagi I, Nagaoka M, Hashimoto S, Aiyama R, Iha M, Ueyama S \& Yokokura T (2000). Properties of fucoidan from Cladosiphon okamuranus Tokida in gastric mucosal protection. Biofactors, 11: 235-245.

30. Mourão PA, Boisson-Vidal C, Tapon-Bretaudiere J, Drouet B, Bros A \& Fischer A (2001). Inactivation of thrombin by a fucosylated chondroitin sulfate from echinoderm. Thrombosis Research, 102: 167-176.

31. Matsubara K, Matsubara Y, Bacic A, Liao M, Horik K \& Miyazawa K (2001). Anticoagulant properties of sulfated galactan preparation from a marine green alga, Codium cylindricum. International Journal of Biological Macromolecules, 28: 395-399.

32. Nagaoka M, Shibata H, Kimura-Tagagi I, Hashimoto S, Aiyama R, Ueyama S \& Yokokua T (2000). Anti-ulcer effects and biological activities of polysaccharides from marine algae. Biofactors, 12: 267-274.

33. Shibata $H$, Nagaoka $M$, Takagi IK, Hashimoto $S$, Aiyama $R$ \& Yokokura T (2001). Effect of oligofucose derivatives on acetic acidinduced gastric ulcer in rats. Bio-Medical Materials and Engineering, 11: 55-61.

34. Vieira LAP (2002). Estudos bioquímicos e farmacológicos das algas Bryothamnion seaforthii (Turner) Kütz, Bryothamnion triquetrum (S.G. Gmel) M. Howe e Botryocladia occidentalis (Borgesen) Kylin. Master's thesis, Universidade Federal do Ceará, Fortaleza, CE, Brazil. 